\title{
Breeding avifauna of the Special Protection Area Natura 2000 'Grądy Odrzańskie' in Czernica and Siechnice counties, Wroclaw district (Poland)
}

Grzegorz Kopij

\begin{abstract}
Breeding avifauna of the Special Protection Area Natura 2000 'Grądy Odrzańskie' in Czernica and Siechnice counties, Wrocław district (Poland). - Acta Mus. Siles. Sci. Natur., 64: 51-67, 2015.

Abstract: In 2009, in the Special Protection Area Natura 2000 'Grądy Odrzańskie' in Czernica and Siechnice counties, Wrocław district, 95 breeding bird species were recorded. For 33 of them, maps of distribution of their breeding pairs are presented and for the remaining a relative abundance was estimated based on line transect method. In 2009, the following species were recorded in the study area for the first time: Cygnus olor, Crex crex, Upupa epops, and Picus canus. On the other hand, 11 species recorded in 1978-87 as breeding in the study area (Ciconia nigra, Pernis apivorus, Milvus migrans, Milvus milvus, Falco tinnunculus, Gallinago gallinago, Limosa limosa, Tringa totanus, Riparia riparia, Anthus campestris, Phoenicurus phoenicurus) were not recorded again in 2009. It has been shown that Saxicola torquata, Ficedula albicollis, Corvus corax and Remiz pendulinus have increased in numbers. The following species recorded in 2009 as breeding in the the study area: Cygnus olr, Ciconia ciconia, Circus aeruginosus, Crex crex, Alcedo atthis, Dryocopus martius, Picus canus, Dendrocopos medius, Lulula arborea, Sylvia nisoria, Ficedula albicollis, Lanius collurio and Emberiza hortulana are included in Annex 1 of the Bird Directive.
\end{abstract}

Key words: nature conservation, censuses, population trends, population estimations.

\section{Introduction}

Natura 2000 is a network of nature protection areas in the territory of the European Union. It is made up of Special Areas of Conservation (SACs) and Special Protection Areas (SPAs). These areas are designated under the Habitats Directive (92/43/EEC) and Birds Directive (79/403/EEC) respectively. SACs and SPAs comprise so called European Ecological Network of Protected Areas. The aim of this Network is to preserve the most representative habitats in Europe, as well as flora and fauna associated with them.

SPAs are designed to protect birds listed in Annex I of the Bird Directive. In each province in Poland, there are usually several SPAs. In Lower Silesia province, 10 such areas were designed to date. The SPA 'Grądy Odrzańskie' [Odra Hornbeam Forests] PLB020002, together with SPA Łęgi Odrzańskie' and SPA 'Dolina Środkowej Odry', plays the most important role in the nature conservation in Silesia. Being located in Odra river valley, these SPAs constitute a backbone of Silesian natural environment, characterised by the highest biodiversity level in the province.

Despite this, the Odra river valley has not attracted special attention of zoologists and ecologists. The breeding avifauna of the especially valuable stretch of this valley between Opole and Wrocław has been a subject of an inventory: the fragment in Opole Silesia in 1999 (Hebda, Wyszyński 2002) and the fragment located within the administrative boundaries of the city of Wrocław in 2003 (Kopij 2008). The breeding avifauna of the remaining stretch of the SPA 'Grądy Odrzańskie' still remains poorely known.

In this paper, the breeding avifauna of the stretch between Łany and Ratnowice has been quantified. The aim of this study was to determine the abundance of all breeding bird species and to present distribution of occupied territories of selected bird species, mostly those of high conservation priorities. An attempt was also undertaken to show qualitative and quantitative changes in the breeding avifauna. 


\section{Study area}

The study area comprised the SPA 'Grądy Odrzańskie' situated in Czernica and Siechnice counties in Wrocław district, Lower Silesia province, in Pradolina Odry macroregion. Description of the natural environment of the whole SPA was published by Kopij (2008) and Wilk et al. (2010).

The surface of the study area is ca. $35 \mathrm{~km}^{2}$, which is $17.5 \%$ SPA 'Grądy Odrzańskie'. On the west, it borders to the fragment of the SPA in the city of Wrocław, where breeding avifauna has been a subject of thorough investigation in 2004 (Kopij 2008). The Olawa river valley constitutes the souther border of the study area, and the Odra river - the northern-eastern border. The administrative border between Siechnice and Oława counties comprises the eastern border.

The study area is located in a flood plain, with numerous rivers, canals, oxbows, drain lines, etc. About half of the area surface is afforested, mainly with Tilio-Carpinetum horn-beam forest (with Quercus robur as a dominant species), with small patches of Alnetum, Fraxino-Alnetum and Pinetum (SW of Kotowice). The open areas comprise a mosaic of arable grounds, meadows, pastures and wetlands. Banks of Oława river are covered with reedbelts, while regulated banks of Odra river are timbered with willows Salix spp., poplars Populus spp. and other tree and shrub species. There are five villages in the study area: large one (Kotowice) and four small ones (Mokry Dwór, Trestno, Blizanowice and Durak).

\section{Study methods}

Studies were conducted in 2009. A simplified version of the territory mapping method (Bibby et al. 1992) was employed. Records were plotted on a map 1: 20 000. Records of a singing male, or an individual showing territorial or breeding behavior (breeding display, nest-building, food-transportation), or an occupied nest (with eggs or chicks), were regarded as a breeding pair, which constituted a census unit in this study (Bibby et al. 1992).

The whole study area was explored three times: 1) from mid-March to the end of April, 2) in May, 3) in June and the first half of July. In total 22 days were devoted to the studies: March: 3 days, April: 7, May: 5, June: 4 and July: 3 days.

Studies were conducted mostly on sunny and windless wheather by walking slowly along roads, pathes, and dikes. Observations were aided with 10 x 50 binoculars.

Relative abundance of birds breeding in forests was determined by means the line transect method (Bibby et al. 1992). Trensects were designed along roads and paths in a way to reflect the proportions of particular forest types and their different age stages. Single counts on transects were conducted in six distinguished periods (Tab 1):

1) Second half of March, time expenditure: 9 hours and 15 min. within 3 days; ca. $18 \mathrm{~km}$

2) First half of April, 10 h., 15 min. within 3 days; ca. 20 km

3) Second half of April, 15 h., 25 min. within 3 days; ca. 30 km

4) Second half of May, 9 h. within 3 days; ca. $18 \mathrm{~km}$

5) First half of June, 10 h., 50 min. within 3 days; ca. 22 km

6) First half of July, 6 h., within 3 days; ca. 12 km

The following parameters were used to describe the avian assemblages (cf. Tab 1): $\mathrm{N}$ - number of pairs recorded, $\% \mathrm{D}$ - dominance (the proportion of resident pairs of a given species to the total number of all breeding pairs of all species recorded, expressed as a percentage), $\mathrm{N}_{\max }$ - maximal number of pairs recorded in any of the six distinguished periods, $\mathrm{D}_{\mathrm{mx}}$. - dominance out of the maximal numbers;

Simpson's Diversity Index (D) was used to calculate diversity of avian assemblages in particular period:

$\mathrm{D}=1-\sum(\mathrm{n} / \mathrm{N})^{2}$, where: $\mathrm{n}$ - total number of pairs of particular bird species; $\mathrm{N}$ - total number of pairs of all bird species; no diversity if $\mathrm{D}=0$; infinite diversity if $\mathrm{D}=1$

Dominant species is defined here as comprising at least $5 \%$ of the total number of all breeding pairs; while subdominant that comprising $2-4.9 \%$ of that total.

Distribution of breeding pairs (=occupied territories) of some uncommon species (e.g. raptors, most waterfowl and waders) or species with high conservation priorities (e.g. Picus canus, Ficedula albicollis, Acrocephalus arundinaceus, A. scirpaceus, Locustella spp.) has been shown on maps (Fig. 1-18). 


\section{Systematic review of species}

Species which were recorded for the first time in the study area in 2009 are indicated with an astersik $(*)$. Species recorded as breeding in the past and not confirmed as breeding in 2009 are indicated with a cross $(+)$.

* Cygnus olor. It nested in an oxbow in Oława river valley near the railway bridge near Siechnice (11.06.2009 - 6 pull.); there was aslo one non-breeding pair there. In the same year another pair nested on Oława just on the border between Siechnice county and Wrocław city. One non-breeding pair was also recorded in the Lake Bajkał. In 1978-87 not recorded as breeding (Dyrcz et al. 1991).

+Ciconia nigra. In 1978-87, it nested near Siechnice (Dyrcz et al. 1991).

Ciconia ciconia. In 2010, one bird occupied a nest in Kotowice (HB1).

Anas platyrhychos. Fairly common all over the area.

Anas querquedula. In 2009, one pair probably nested in an oxbow near Gajków.

+Mergus merganser. It nested near Kotowice in the end of 19th century (Kollibay 1906).

Phasianus colchicus. Fairly common in the whole study area.

Podiceps cristatus. In 2010, 1-2 probably breeding pairs in Lake Bajkał.

+Nycticorax nycticorax. In1899, it nested near Kotowice. This site was in that time one of three known breeding sites of this species in Silesia (Glutz von Blotzheim 1966). On 24.04.2009, one bird was recorded in willows in Lake Dziewicze (Odra oxbow).

+Pernis apivorus. In 1978-87, single pairs nested near Siechnice and Siedlec (Dyrcz et al. 1991).

+Milvus migrans. In1978-87, single pairs nested on Odra River near Łany, Gajków and on Oława near Siechnice (Dyrcz et al. 1991).

+ Milvus milvus. In 1978-87, one pair nested near Janowice (Dyrcz et al. 1991).

Circus aeruginosus. In 2009, single pairs nested on Oława near Siechnice and Durok. In1978-87, single breeding pairs were recorded on Odra near Kamieniec and on Oława near Siechnice, and 2-5 pairs in a marshland near Ratnowice (Dyrcz et al. 1991).

Accipiter gentilis. In 2009, an occupied territory was located S of Kotowice (Fig 1) and probably another pair nested near Gajków. In 1978-87, nesting was recorded near Łany and Siechnice (Dyrcz et al. 1991).

Buteo buteo. In 2009, 11 occupied territories were identified (Fig 1).

+Falco tinnunculus. In 2009, it was not recorded. In 1978-87, signgle pairs nested near Łany and Siechnice (Dyrcz et al. 1991).

*Crex crex. On 17.05.2009, one male was heared in a marshland on the left bank of Odra just below Czernica. It was not recorded in 1978-87.

Gallinula chloropus. In 2009, only 2-3 pairs were recorded in Odra oxbows. However, this figure is probably underestimated.

+Gallinago gallinago. In 1978-87, a lek with few males was localized in a marshland on Odra near Ratnowice (Dyrcz et al. 1991).

+ Limosa limosa. In 1978-87, a site with a few displaying males was situated in a marshland on Odra near Ratnowice (Dyrcz et al. 1991).

Vanellus vanellus. In 2009, only one pair was recorded in arable grounds between Trestno and Mokry Dwór.

+Tringa totanus. In 1978-87, a site with 1-2 displaying males was situated in a marshland on Odra near Ratnowice (Dyrcz et al. 1991).

Streptopelia turtur. Only on 29.4.2009 one male was heared on Odra between Gajków and Jeszkowice.

Streptopelia decaocto. Common breeding in human settlements (e.g. in Kotowice: 8-10 pairs); uncommon on forest edges. 
Columba palumbus. Fairly common all over the study area.

Cuculus canorus. In 2009, 16 male territories were identified (Fig 2).

Strix aluco. Fairly common in forests.

Asio otus. Uncommon on ferest edges.

Apus apus. In 2009, 2 pairs nested in Mokry Dwór.

Alcedo atthis. In 2009, 2 pairs were recorded (Fig 2). In 1978-87, only one pair nested on Oława near Siechnice (Dyrcz et al. 1991).

* Upupa epops. In 2009, one pair nested on Oława near Groblice and on Odra near Trestno (Fig 2). In 1978-87, not recorded (Dyrcz et al. 1991).

Jynx torquilla. In 2009, 13 pairs were recorded (Fig 3).

*Picus canus. In 2009, 4 pairs nested (Fig 4). In 1978-87, it was not recorded (Dyrcz et al. 1991).

Picus viridis. In 2009, 9 pairs were recorded (Fig 4).

Dryocopus martius. In 2009, 6 pairs nested (Fig 3).

Dendrocopos major. It was classified as subdominant in forests (c. 4\%; Tab 1).

Dendrocopos medius. In 2009, 9 pairs were recorded in old oak stands (Fig 5).

Dendrocopos minor. In 2009, 5 breeding pairs were recorded (Fig 5).

Alauda arvensis. Fairly common in arable grounds.

Lulula arborea. In 2009, 3 pairs were recorded (Fig 6).

+Riparia riparia. In 1978-87, a colony of several dozen nests was located in Odra bank near Ratnowice (Dyrcz et al. 1991).

Hirundo rustica. It nested in all villages: Kotowice: > 30 pairs, Mokry Dwór: >10 pairs, Trestno: $>10$ pairs.

Delichon urbica. A colony of ca. 100 nests were localized on mill-dam near Ratnowice. Dozen or so pairs nested also in Kotowice, and each few pairs in Trestno and Mokry Dwór.

+Anthus campestris. In 1978-87, one pair nested near Gajków (Dyrcz et al. 1991).

Anthus trivialis. In 2009, 17 pairs were recorded (Fig 6), but the figure was probaly underestimated.

Motacilla flava. Fairly common in arable grounds and meadows.

Motacilla alba. Fairly common all over the area.

Troglodytes troglodytes. In 2009, 9 pairs were recorded (Fig 7), but the figure could have been underestimated.

Prunella modularis. Uncommon in forests only (Tab 1).

Erithacus rubecula. Common in forests, where it was classified as subdominant (ca. 4\%; Tab 1).

Luscinia megarhynchos. In 2009, 56 pairs were recorded (Fig 8), including 36 pairs along Odra, canals and around Lake Bajkał.

Phoenicurus ochruros. It nested only in human settlements; in Kotowice: 11 pairs and each of 2-4 pairs in other villages.

+Phoenicurus phoenicurus. In 2009, it was not recorded. In 1978-87, it was a breding species.

Saxicola rubetra. Fairly common in arable fields, meadows and forest edges.

Saxicola torquata. In 2009, 6 pairs were recorded (Fig 9). In 1978-87, only 2 sites with single (?) pairs were recorded: near Siechnice and Kotowice (Dyrcz et al. 1991). The site near Siechnice was known as early as 1936/37 (Bodle 1936, 1937 in Glutz von Blotzheim 1988) and confirmed in 1971 (Glutz von Blotzheim 1988). In that time it was one of only few breeding localities of this species in Silesia (Glutz von Blotzheim 1988, Dyrcz et al. 1991).

Turdus merula. Very common. In forests, it was a dominant species (4-5\%; Tab 1). Numerical proportion between T. merula and T. philomelos was in forests as $0.59: 0.41$ ( $n=363$ pairs of both species). 
Turdus pilaris. Fairly common on rivers, canals and in some afforestations.

Turdus philomelos. Very common in forests, where it was classified as subdominant (Tab 1).

Turdus viscivorus. In 2009, only 3 pairs were recorded.

Locustella naevia. In 2009, 24 were recorded (Fig 10), most nested on Odra River.

Locustella fluviatilis. In 2009, 17 pairs were recorded (Fig 10).

Locustella luscinioides. On 24.5.2009, one male was singing in a reed belt on Oława on the border with Wrocław city. In 1978-87, two sites with singing males were localized on Odra near Łany and Ratnowice, and on Oława near Siechnice (Dyrcz et al. 1991).

Acrocephalus schoenobaenus. In 2009, 6 pairs were recorded (Fig 11).

Acrocephalus palustris. Common breeding in grasses and sedges on forest edges, along canals, rivers and plots with cultivated plants.

Acrocephalus scirpaceus. In 2009, 42 pairs were recorded, including 31 pairs in Oława river valley covered with reeds (Fig 12).

Acrocephalus arundinaceus. In 2009, 54 pairs were recorded, with almost half of them in Oława river valley covered with reeds (Fig 13).

Hippolais icterina. Fairly common in forests and groves.

Sylvia nisoria. In 2009, 7 pairs were recorded (Fig 14).

Sylvia curruca. Fairly common in arable grounds, meadows, forest edges and human settlements.

Sylvia communis. Fairly common in arable grounds, meadows and forest edges.

Sylvia borin. Fairly common all over the area.

Sylvia atricapilla. It was a dominant species in forests (6-7\%; Tab 1). The proportion among breeding pairs of S.atricapilla : S.communis : S.curruca : S.borin : S.nisoria was as 0.81 : $0.12: 0.04: 0.03: 0.01$ ( $\mathrm{n}=312$ pairs of all Sylvia species).

Phylloscopus sibilatrix. Fairly common in forests.

Phylloscopus collybita. It was classified as a dominant species in forests (6\%).

Phylloscopus trochilus. It was the least common representative of the genus in forests (Tab 1). However, it was common along some rivers and canals, especially covered with willows.

Regulus regulus. Only a few pairs were recorded in the pine forest on dunes (Fig 16).

Muscicapa striata. It nested in forests and all sort of afforestations, where it was a subdominat species (Tab 1).

Ficedula albicollis. In 2009, 22 pairs were recorded, most in old oak stands (Fig 15).

Aegithalos caudatus. Fairly common in forests and afforestations.

Parus palustris. Fairly common in more humid sites in forests (Tab 1).

Parus ater. Uncommon in pine forests (Tab 1).

Parus caeruleus. It was classified as subdomiant in forests (4-5\%; Tab 1). It nested also in afforestations, groves, and gardens.

Parus major. It nested in all forest types, afforestations, groves and gardens. In forests, it was classified as dominant (Tab 1).

Sitta europaea. It nested in forests (4-5\%; Tab 1) and some larger groves.

Certhia familiaris. In 2009, 11 territories were located (all in oak stands), but the fugure could have been underestimated (Fig 16).

Certhia brachydactyla. Only 4 occupied territories were localized; all were in oak forests (Fig 16).

Remiz pedulinus. In 2009, 10 pairs were recorded (Fig 7). The site at Mokry Dwór is very stable one, known already in 19th century (Kollibay 1906, Pax 1925). The breeding site was confirmed by Merkel $(1932,1935)$ in the early 1930's and again by G. Kopij, J. Kusznierz and B. Najbar in 1984-1988.

Oriolus oriolus. In 2009, 42 pairs were recorded, evenly distributed all over the area (Fig 17). 
Lanius collurio. In 2009, 19 pairs were recorded (Fig 14), and the whole population was estimated at 30-50 pairs.

Lanius excubitor. Only one occupied territory was localized near Trestno.

Garrulus glandarius. Fairly common in forests (Tab 1).

Pica pica. Fairly common in farmlands.

Corvus cornix. In 2009, 9 pairs were recorded (Fig 18), but numbers could have been underestimated.

Corvus corax. In 2009, 2 pairs were recorded (Fig 18). In 1978-87, one pair nested near Kotowice.

Sturnus vulgaris. Second to Fringilla coelebs most common bird species in forests (7-9\%; Tab 1).

Passer domesticus. Common breeding in human settlements.

Passer montanus. Common on forest edges and in some afforestations.

Fringilla coelebs. The most common breeding species in forests (13-16\%; Tab 1).

Serinus serinus. Common breeding in the whole area.

Carduelis chloris. Fairly common in the whole area.

Carduelis carduelis. Common in forest edges, afforestations and in human settlements.

Carduelis cannabina. Fairly common in farmlands.

Coccothraustes coccothraustes. Common breeding in forests (2-3\%; Tab 1).

Emberiza citrinella. Very common, especially on forest edges and parklands.

Emberiza hortulana. In 2009, only one territory was localized in arable grounds S of Kotowice (Fig 9).

Emberiza schoeniclus. Common, especially in reed belts along rivers and canals.

Miliaria calandra. In 2009, 21 pairs were recorded (Fig 9).

\section{Results of quantitative studies on birds breeding in forests}

In total, 64 bird species were recorded by means of line transect method as breeding in forests. The group of domiants was represented by Fringilla coelebs, Sturnus vulgaris, Sylvia atricapilla, Parus major, Phylloscopus collybita and Emberiza citrinella. The group of subdominants included: Turdus merula, T. philomelos, Parus caeruleus, Sitta europaea, Coccothraustes coccothraustes, Erithacus rubecula and Dendrocopos major (Tab 1).

For most species, the dominance have changed significantly from period to period, e.g. Fringilla coelebs: 11.5 - 20.9, Sturnus vulgaris: 0 - 14.7, Parus major: 1.8 - 11.1, Phylloscopus collybita: 0.8 - 9.5, Emberiza citrinella: 1.0 - 11.9, Turdus merula: 3.3 - 13.0, etc. It is, therefore, imperative to conduct studies on avian structure by means of the line transect method in the whole breeding season ([second half of March] April-June [first half of July]), not only in one month, as practised by some researchers.

The Simpson's Diversity Index was above 0.90 in each of the six distinguished periods, being slightly higher in May and June (0.93-0.95) than in remaining months (0.90-0.91) (Tab 1). The overall Simpson's Diversity Index was $S=0.94$.

\section{Conclusion}

In 2009, 95 breeding bird species were recorded in the SPA 'Grądy Odrzańskie' in Czernica and Siechnice counties, Wrocław district. This constitutes $44.7 \%$ of all breeding bird species recorded in Poland during the years 1990-2004 (Sikora et al. 2007) and 54.8\% of all breeding bird species recorded in Silesia during the years 1978-87 (Dyrcz et al. 1991). In the whole SPA 'Grądy Odrzańskie' (200 km²), 113 breeding species were recorded to date (Wilk et al. 2010). Out of 95 bird species recorded as breeding in 2009 in the SPA 'Grądy Odrzańskie' in Czernica and Siechnice counties, 29 (30.5\%) belong to Non-Passeriformes, a $66(69.5 \%)$ to Passeriformes. 
In 2009, the following species were recorded for the first time as breeding in the study area: Cygnus olor, Crex crex, Upupa epops, and Picus canus. The following species, which were recorded as breeding in 1978-87, were not recorded as such in 2009: Ciconia nigra, Pernis apivorus, Milvus migrans, Milvus milvus, Falco tinnunculus, Gallinago gallinago, Limosa limosa, Tringa totanus, Riparia riparia, Anthus campestris and Phoenicurus phoenicurus (Dyrcz et al. 1991). Two species Mergus merganser and Nicticorax nycticorax were recorded as breeding in the 19th century and never again (Kollibay 1906). For the following species an increase in their numbers was shown: Saxicola torquata, Ficedula albicollis, Corvus corax and Remiz pendulinus. A decline was shown for Ciconia ciconia.

The following species recorded in 2009 as breeding in the the study area: Cygnus olor, Ciconia ciconia, Circus aeruginosus, Crex crex, Alcedo atthis, Dryocopus martius, Picus canus, Dendrocopos medius, Lulula arborea, Sylvia nisoria, Ficedula albicollis, Lanius collurio and Emberiza hortulana are included in Annex 1 of the Bird Directive (Directive 79/409/ECW from 02.04.1979), and therefore require special protection. The boundaries of the SPA 'Grądy Odrzańskie', and the very existance of this protected area depends largly upon the ocurrence and population densities of these species. Monitoring their numbers on a regular basis in this area is, therefore, highly desired.

\section{References}

Dyrcz A., Grabiński W., Stawarczyk T. \& Witkowski J. (1991): Ptaki Śląska - monografia faunistyczna. Wrocław: Uniw. Wrocławski.

Glutz von Blotzheim U.N. (ed.) (1966): Hanbuch der Vögel Mitteleuropas. Tom 1. Wiesbaden: AULAVerlag.

- (red.) (1988): Hanbuch der Vögel Mitteleuropas. Tom 11/1. Wiesbaden: AULA-Verlag.

Hebda G. \& Wyszyński M. (2002): Awifauna lęgowa fragmentu Doliny Odry w województwie opolskim. Ptaki Śląska 14: 47-62.

Kollibay P. (1906): Die Vögel der Preussischen Provinz Schlesien. Breslau.

Kopij G. (2008): Awifauna lęgowa Obszaru Specialnej Ochrony Natura 2000 "Grądy Odrzańskie" we Wrocławiu. - Parki Narodowe i Rezerwaty Przyrody 27(4): 95-114.

Merkel F.W. (1932) : Zur Brutbiologie der Beutelmeise, Remiz pendulinus L., in Schlesien. - J. Orn. 80 : $275-$ 284.

- (1935): Zur Fortpflanzugbiologie der Beutelmeise (Remiz p. pendulinus) in Schlesien. - Ber. Ver. Schles. Orn., 20: $1-9$.

Pax F. (1925): Wirbeltierfauna von Schlesien. Berlin: Gebrüder Borntraeger.

Sikora A., Rohde Z., Gromadzki M., Neubauer G. \& Chylarecki P. (eds) (2007): Atlas rozmieszczenia ptaków lęgowych Polski 1985-2004. Poznań, Bogucki Wyd. Nauk.

Tomiałojć L. \& Profus P. (1977): Comparative analysis of breeding bird communities in two parks of Wrocław and in an adjacent Querco-Carpinetum forest. - Acta orn. 16: 117-177.

Wilk T., Jujka M., Krogulec J. \& Chylarecki P. (eds) (2010): Ostoje ptaków o znaczeniu międzynarodowym w Polsce. Marki, OTOP.

Author's address: Grzegorz Kopij, Department of Wildlife Management, University of Namibia, Private Bag 1096, Wenela Rd., Katima Mulilo, Namibia

E-mail: gkopij@unam.na 


\section{Appendix:}

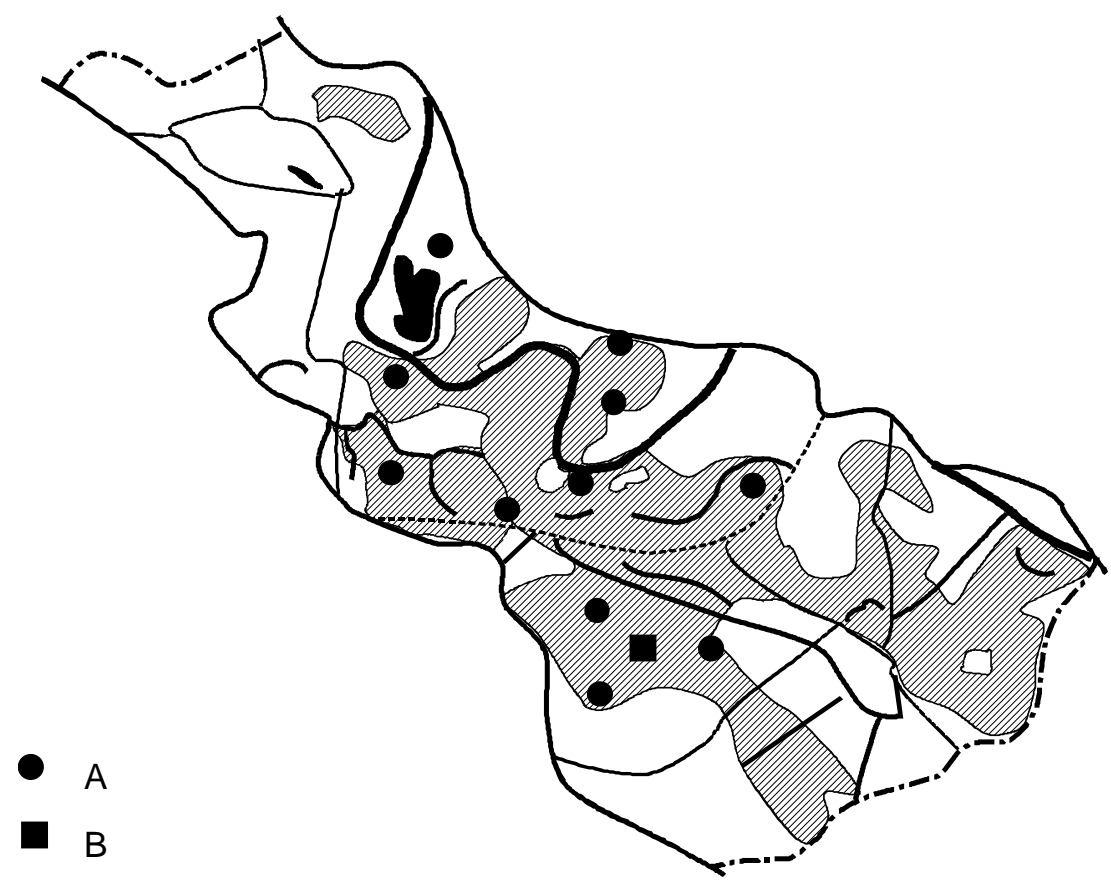

Fig 1: Distribution of Buteo buteo (A) and Accipiter gentilis (B) breeding pairs in Special Protection Area Natura 2000 "Grądy Odrzański” in Czernica and Siechnice counties, Wrocław district in 2009.

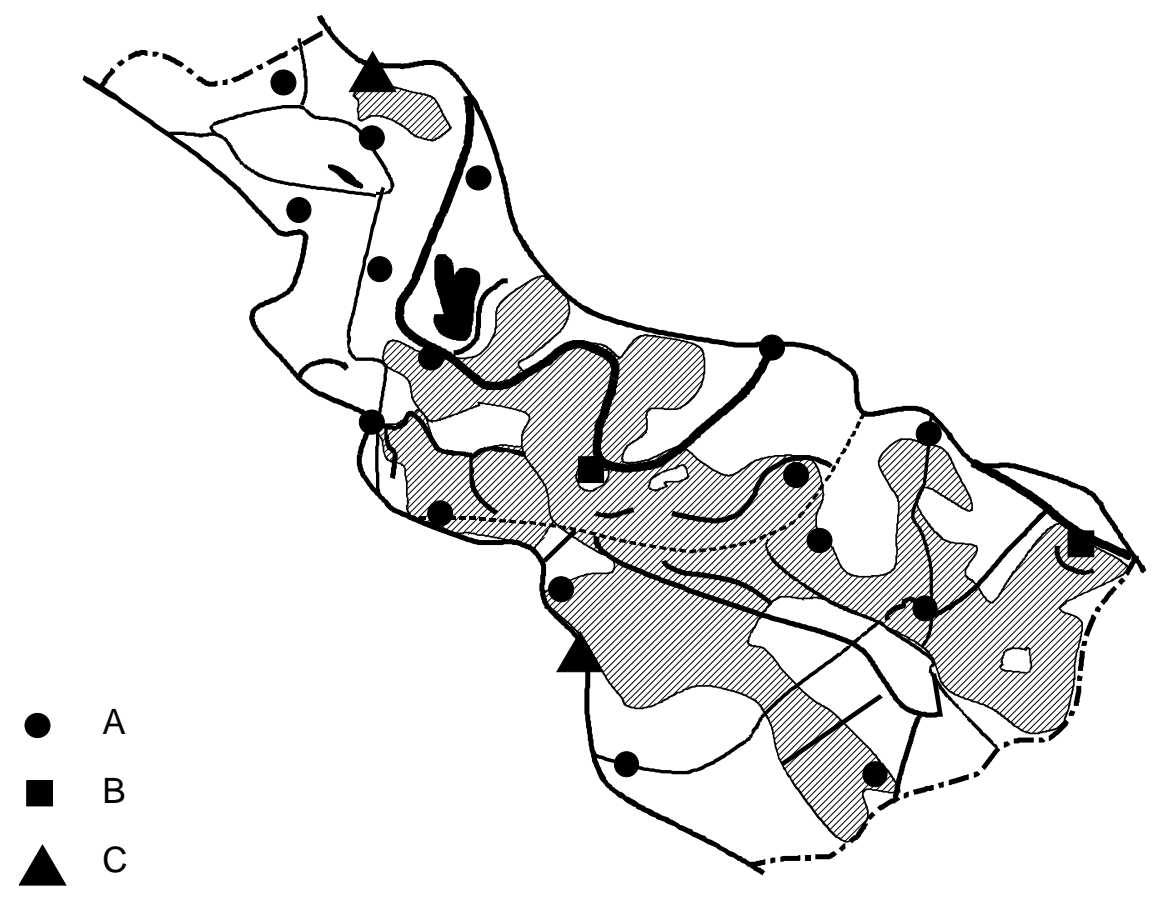

Fig 2: Distribution of Cuculuc canorus (A), Alcedo atthis (B) and Upupa epops (C) breeding pairs in Special Protection Area Natura 2000 "Grądy Odrzański” in Czernica and Siechnice counties, Wrocław district in 2009. 


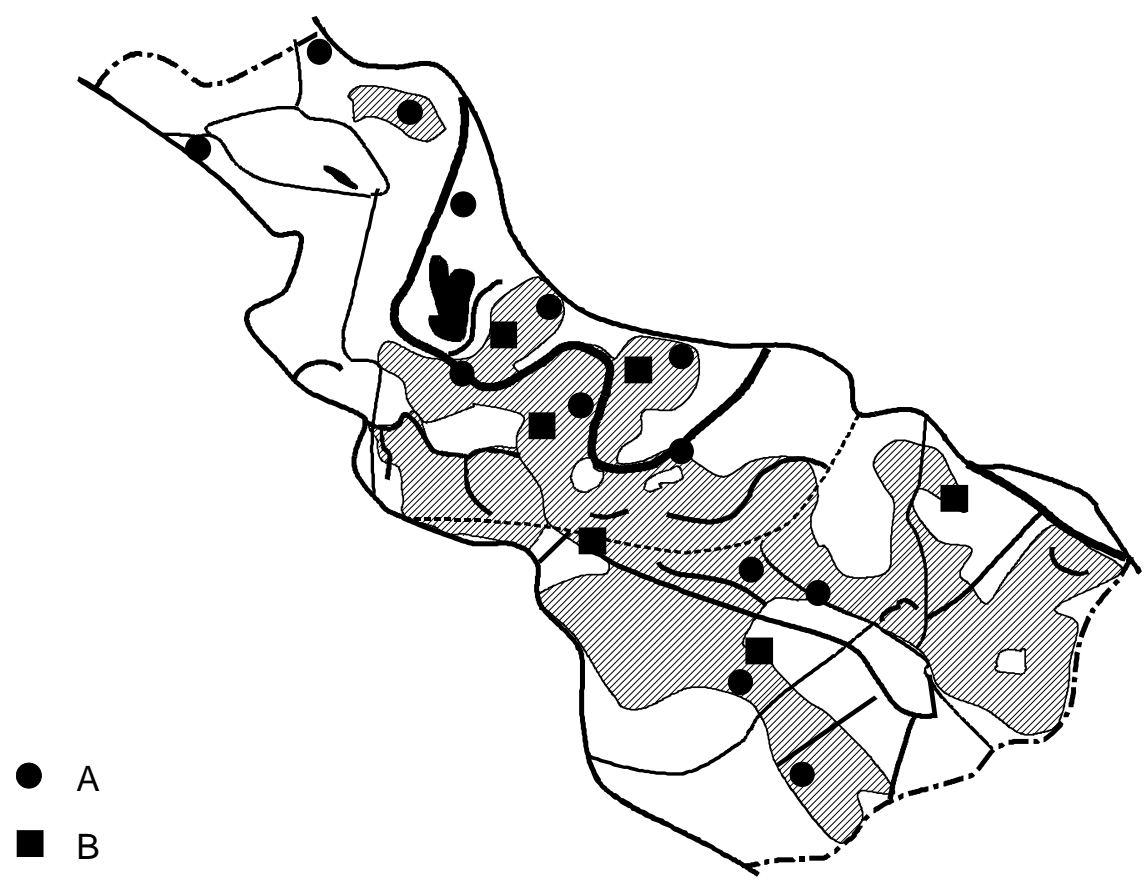

Fig 3: Distribution of Dryocopus martius (B) and Jynx torquilla (A) breeding pairs in Special Protection Area Natura 2000 "Grądy Odrzański” in Czernica and Siechnice counties, Wrocław district in 2009.

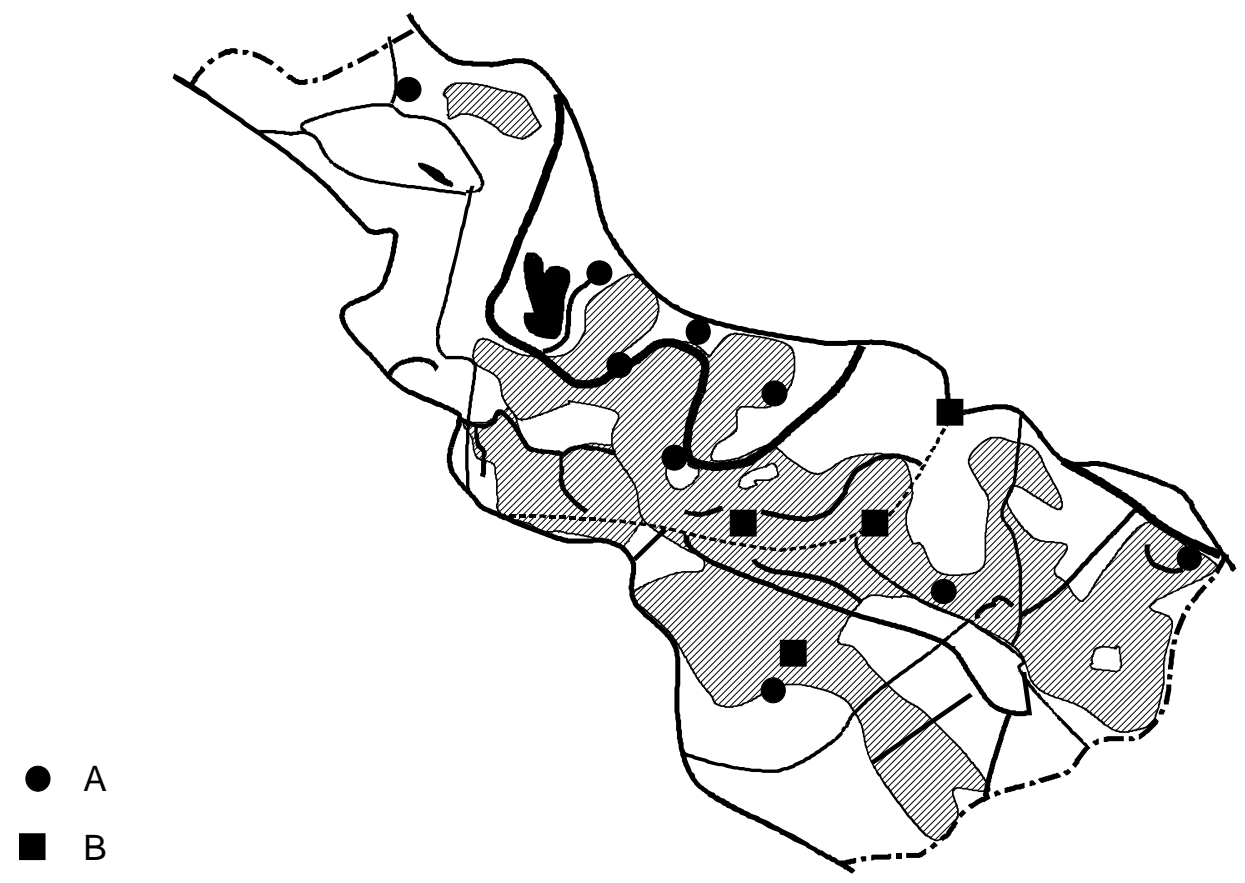

Fig 4: Distribution of Picus viridis (A) and Picus canus (B) breeding pairs in Special Protection Area Natura 2000 "Grądy Odrzański” in Czernica and Siechnice counties, Wrocław district in 2009. 


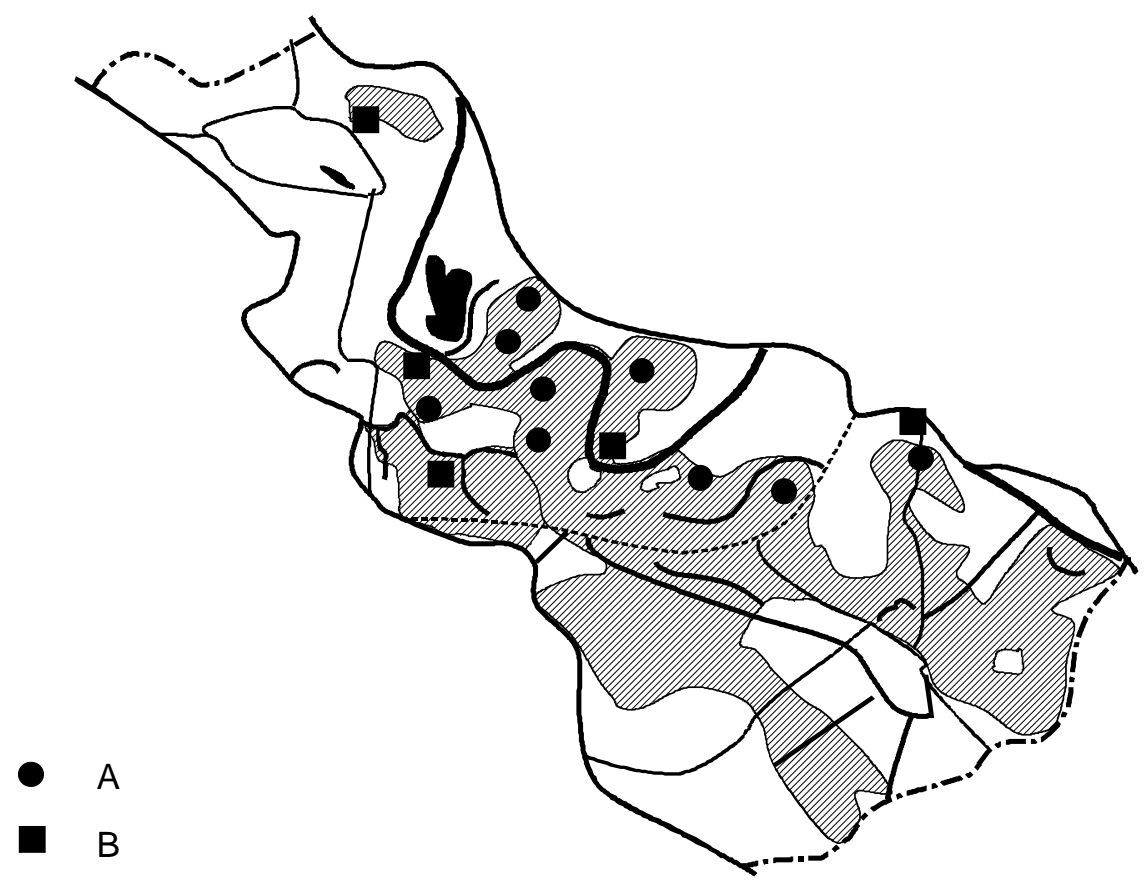

Fig 5: Distribution of Dendrocopos medius (A) and Dendrocopos minor (B) breeding pairs in Special Protection Area Natura 2000 “Grądy Odrzański” in Czernica and Siechnice counties, Wrocław district in 2009.

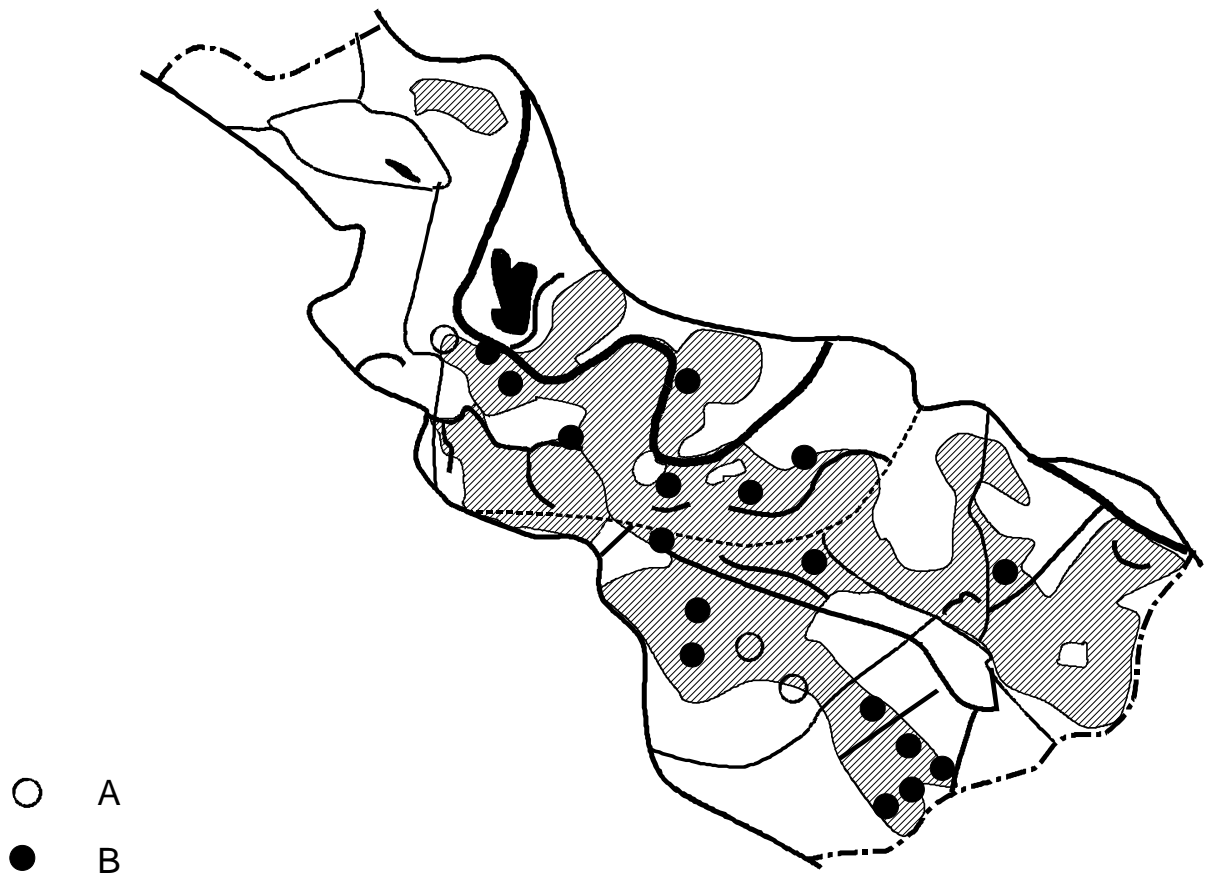

Fig 6: Distribution of Lulula arborea (A) i Anthus trivialis (B) breeding pairs in Special Protection Area Natura 2000 "Grądy Odrzański” in Czernica and Siechnice counties, Wrocław district in 2009. 


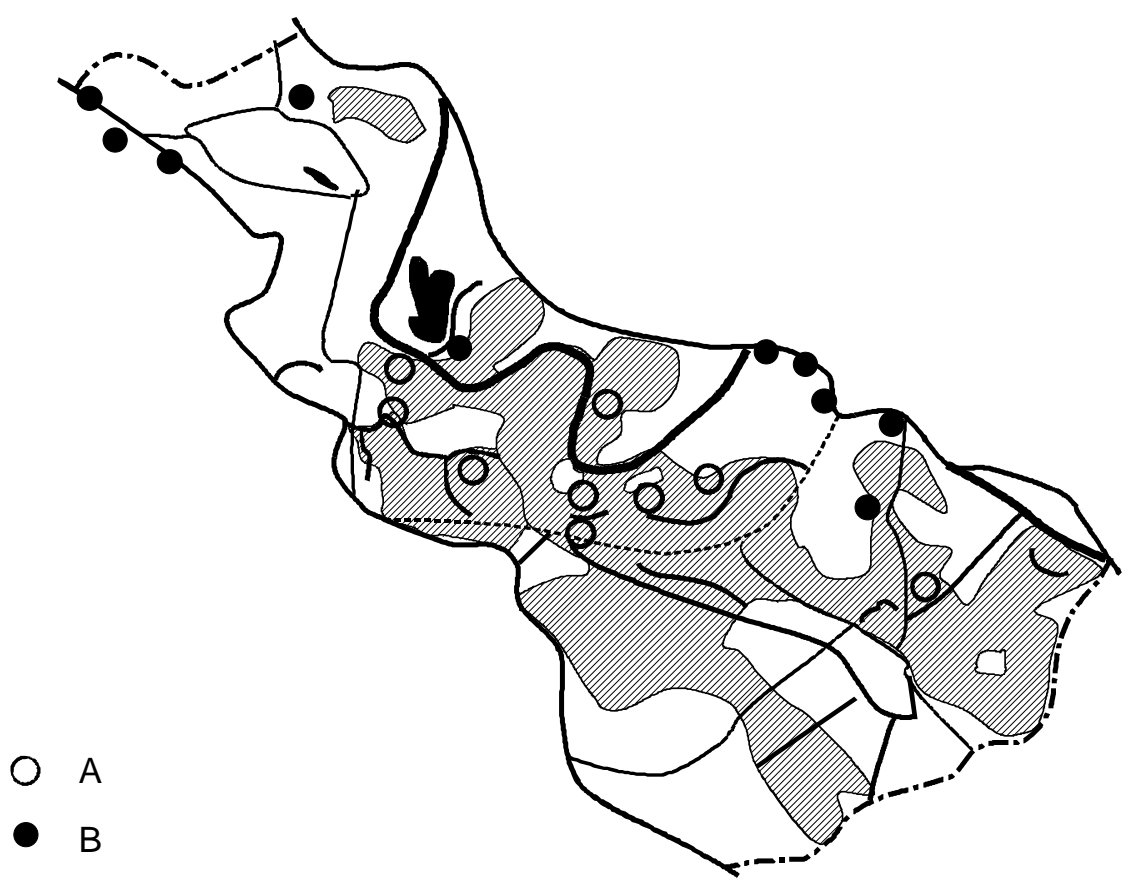

Fig 7: Distribution of Troglodytes troglodytes (A) and Remiz pendulinus (B) breeding pairs in Special Protection Area Natura 2000 “Grądy Odrzański” in Czernica and Siechnice counties, Wrocław district in 2009.

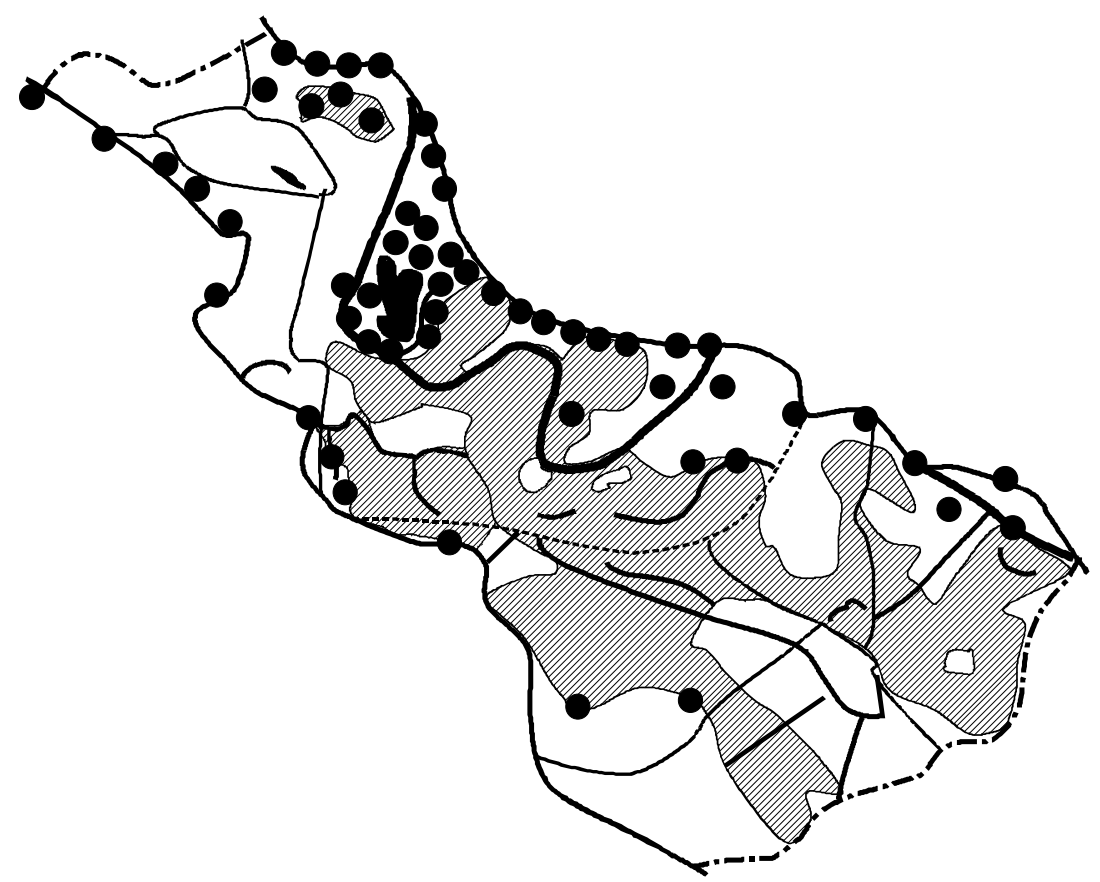

Fig 8: Distribution of Luscinia magerhynchos breeding pairs in Special Protection Area Natura 2000 "Grądy Odrzański" in Czernica and Siechnice counties, Wrocław district in 2009. 


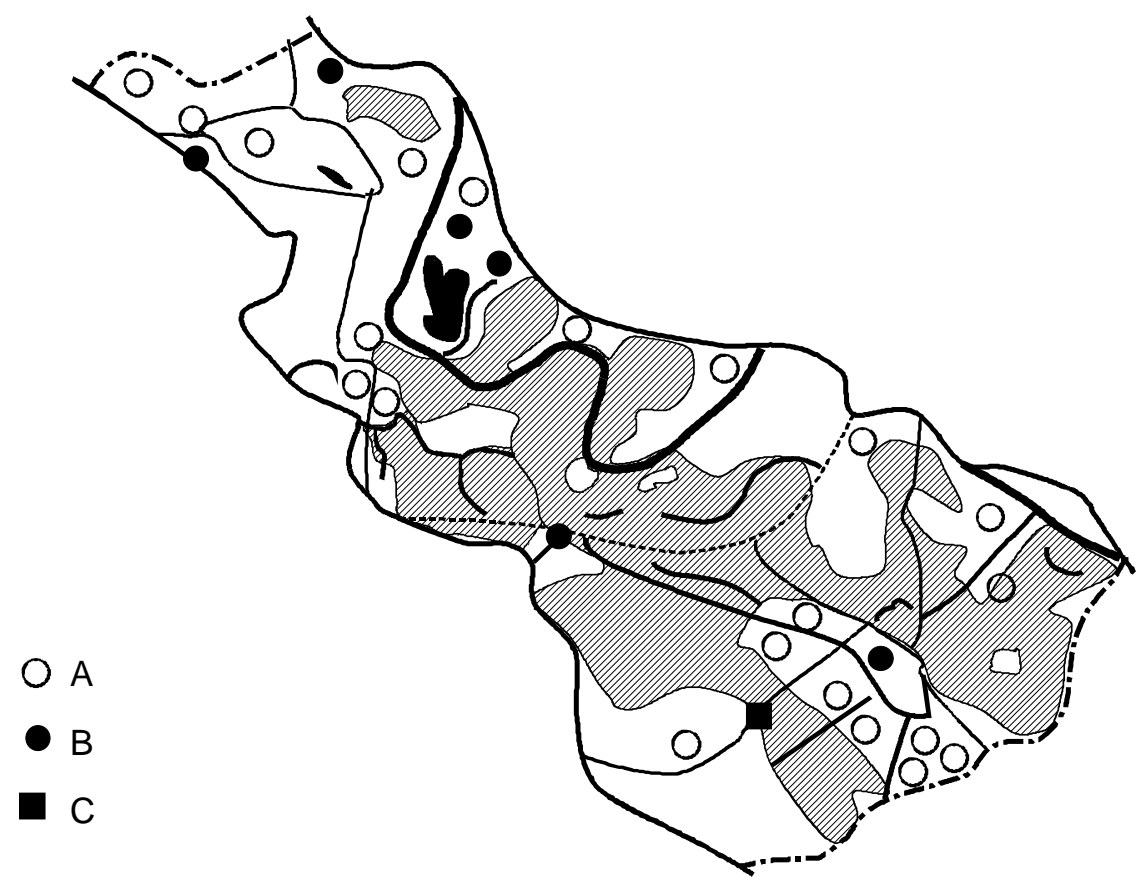

Fig 9: Distribution of Miliaria calandra (A), Saxicola torquata (B) and Emberiza hortulana (C) breeding pairs in Special Protection Area Natura 2000 "Grądy Odrzański” in Czernica and Siechnice counties, Wrocław district in 2009.

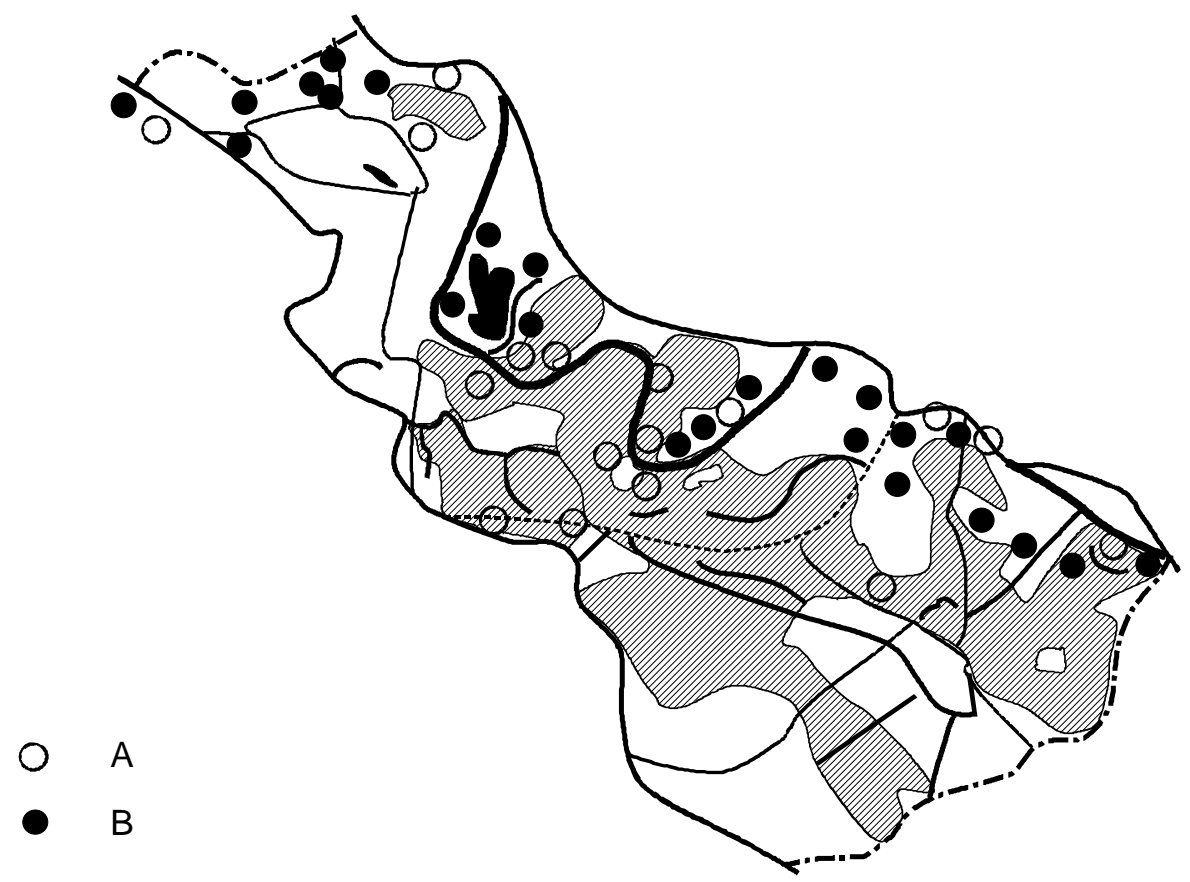

Fig 10: Distribution of Locustella fluviatilis (A) and Locustella naevia (B) breeding pairs in Special Protection Area Natura 2000 "Grądy Odrzański” in Czernica and Siechnice counties, Wrocław district in 2009. 


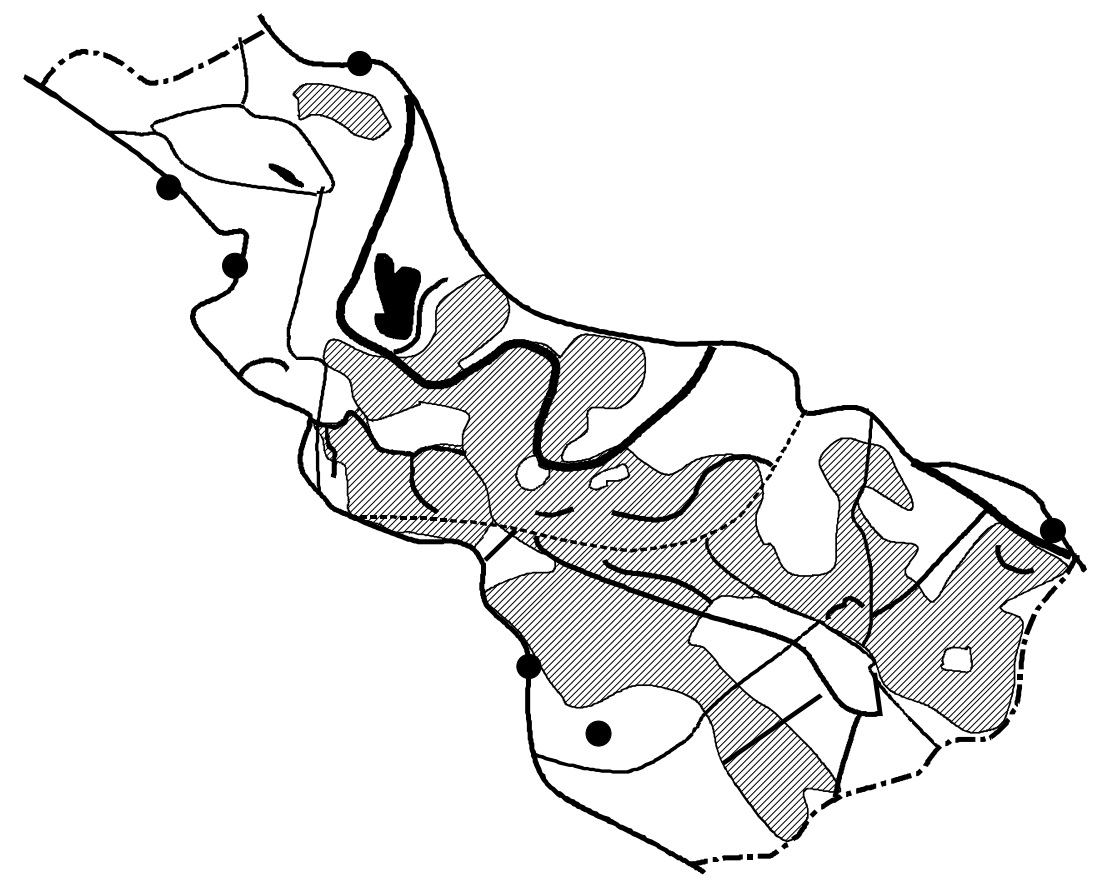

Fig 11: Distribution of Acrocephalus schoenobaenus breeding pairs in Special Protection Area Natura 2000 "Grądy Odrzański” in Czernica and Siechnice counties, Wrocław district in 2009.

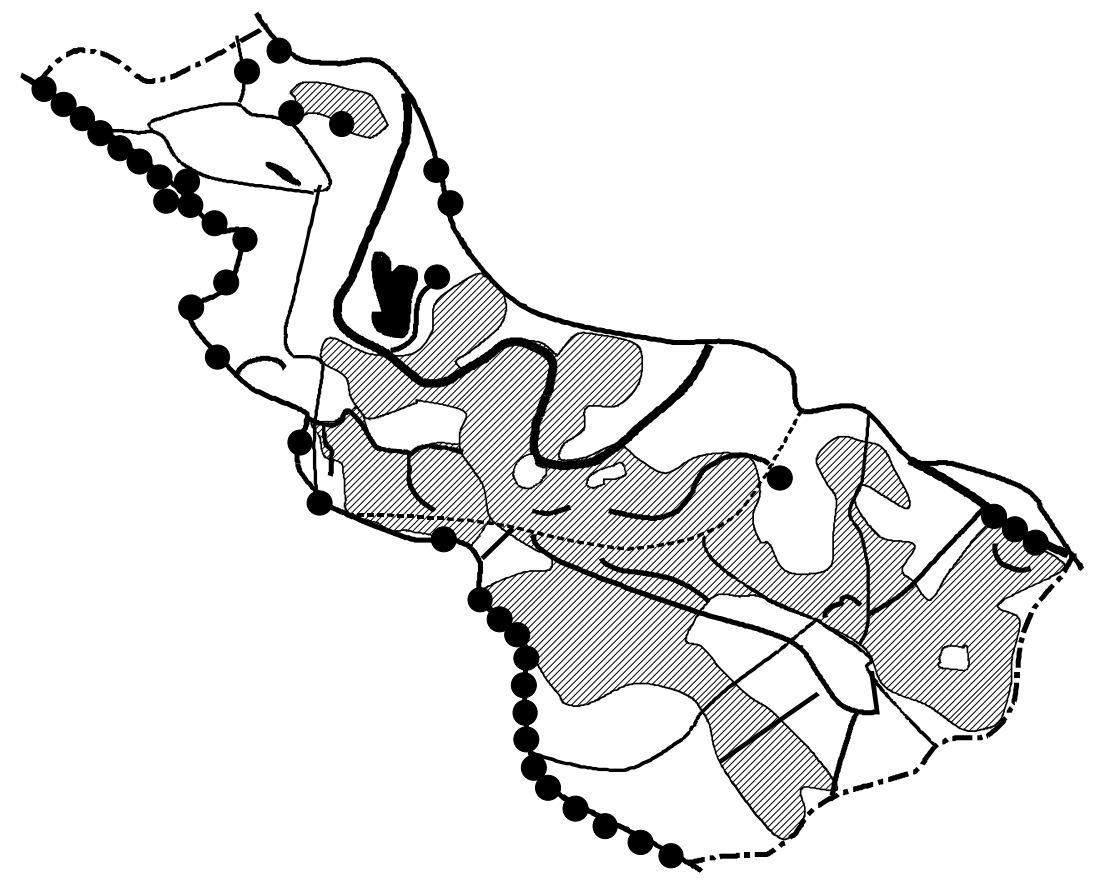

Fig 12: Distribution of Acrocephalus scirpaceus breeding pairs in Special Protection Area Natura 2000 "Grądy Odrzański" in Czernica and Siechnice counties, Wrocław district in 2009. 


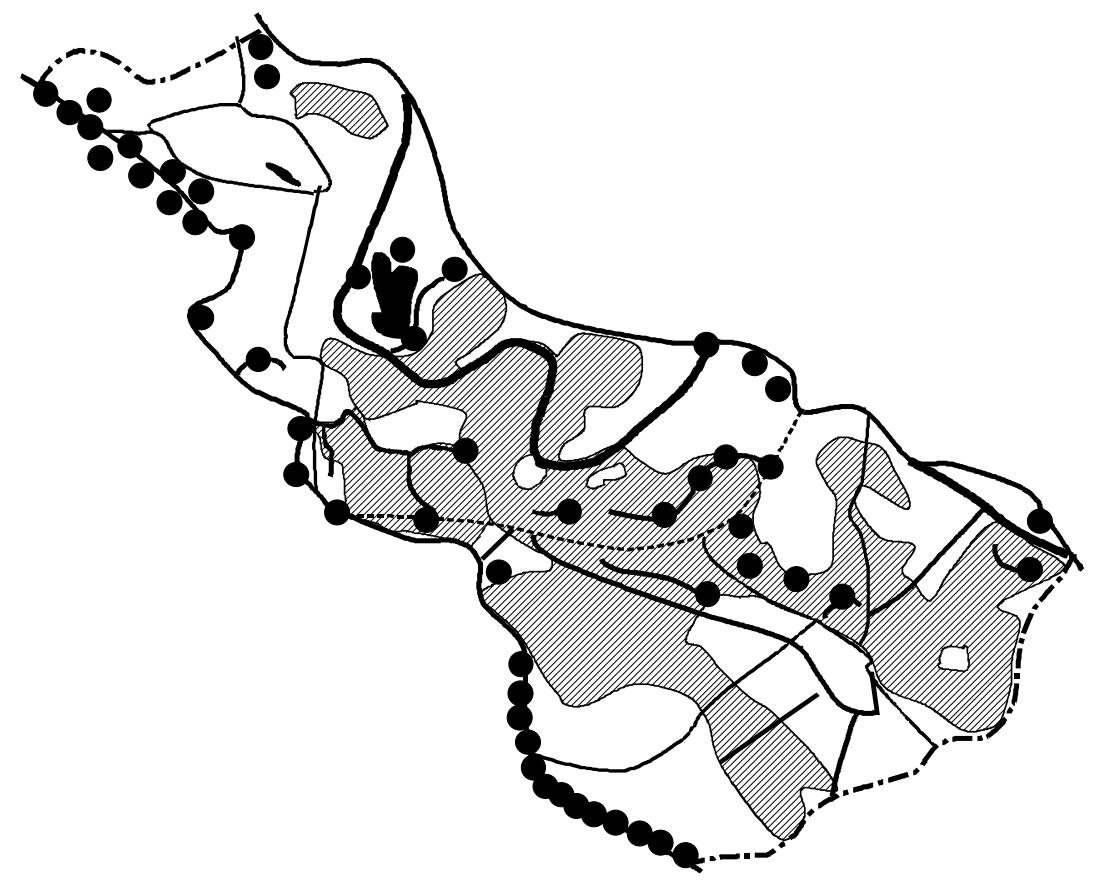

Fig 13: Distribution of Acrocephalus arundinaceus breeding pairs in Special Protection Area Natura 2000 "Grądy Odrzański” in Czernica and Siechnice counties, Wrocław district in 2009.

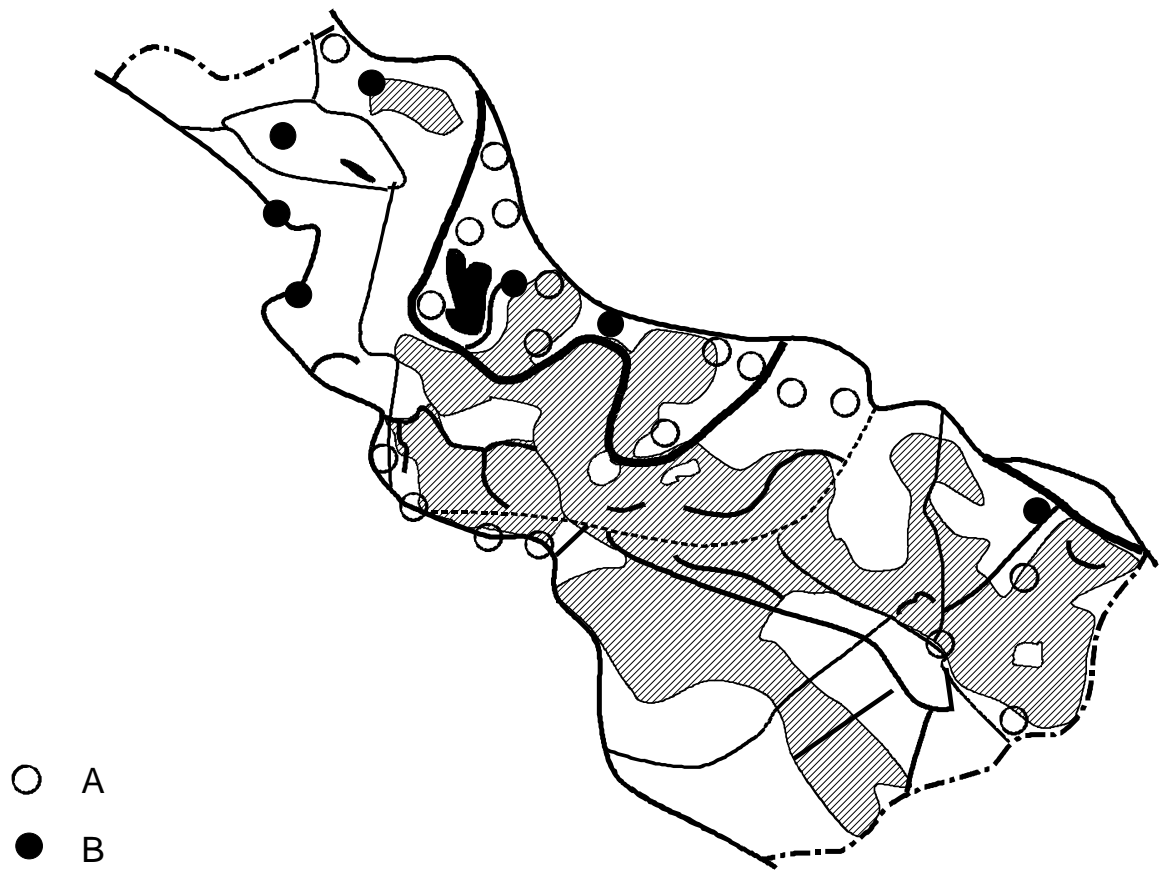

Fig 14: Distribution of Lanius collurio (A) and Sylvia nisoria (B) breeding pairs in Special Protection Area Natura 2000 "Grądy Odrzański” in Czernica and Siechnice counties, Wrocław district in 2009. 


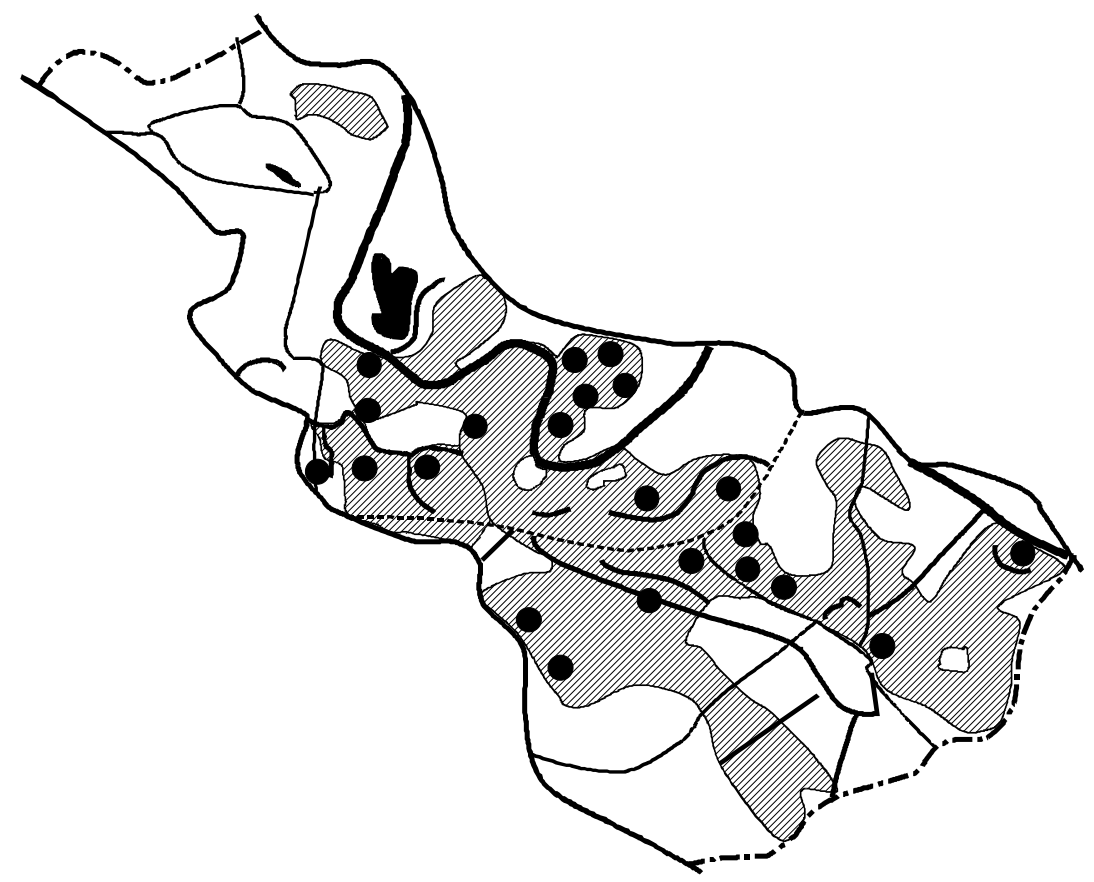

Fig 15: Distribution of Ficedula albicollis breeding pairs in Special Protection Area Natura 2000 "Grądy Odrzański” in Czernica and Siechnice counties, Wrocław district in 2009.

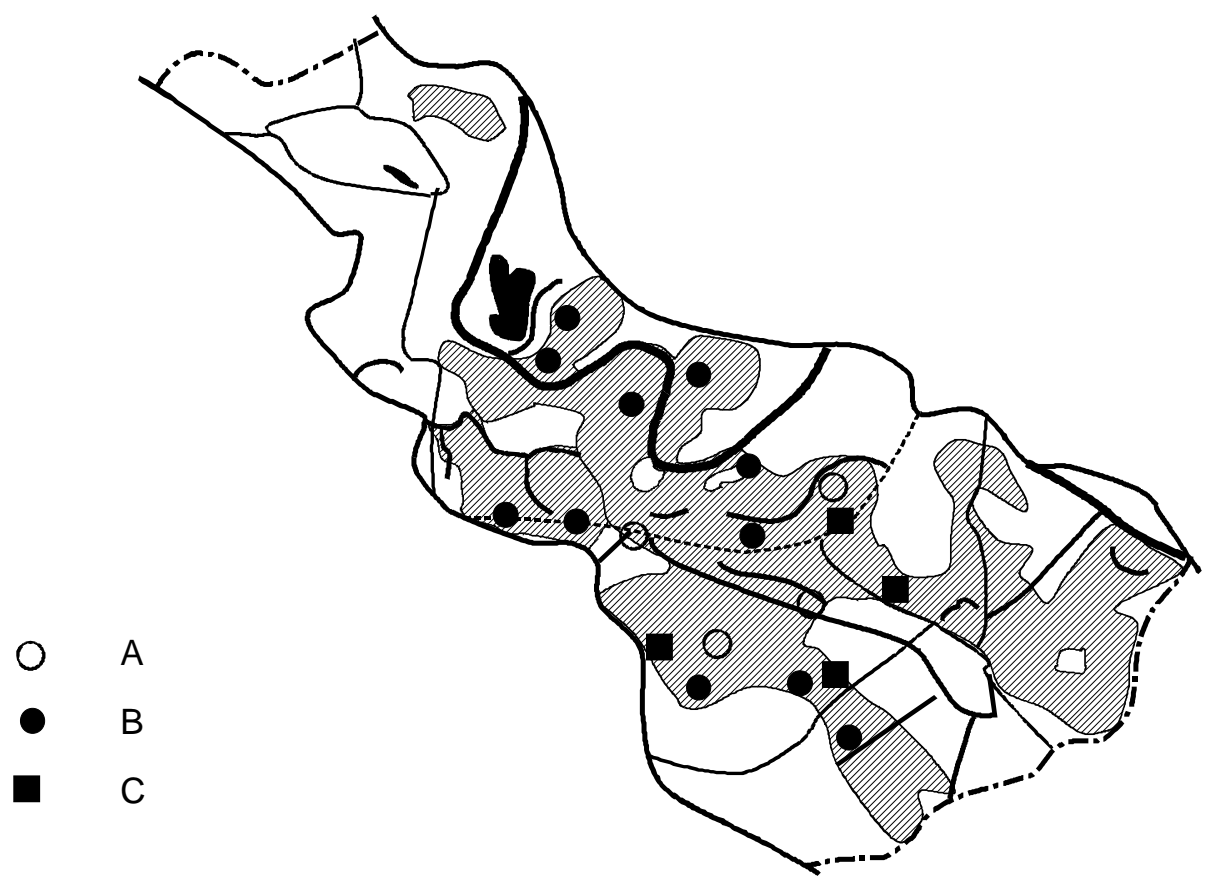

Fig 16: Distribution of Certhia familairis (B), Certhia brachydactyla (C), Regulus regulus (A) breeding pairs in Special Protection Area Natura 2000 "Grądy Odrzański” in Czernica and Siechnice counties, Wrocław district in 2009. 


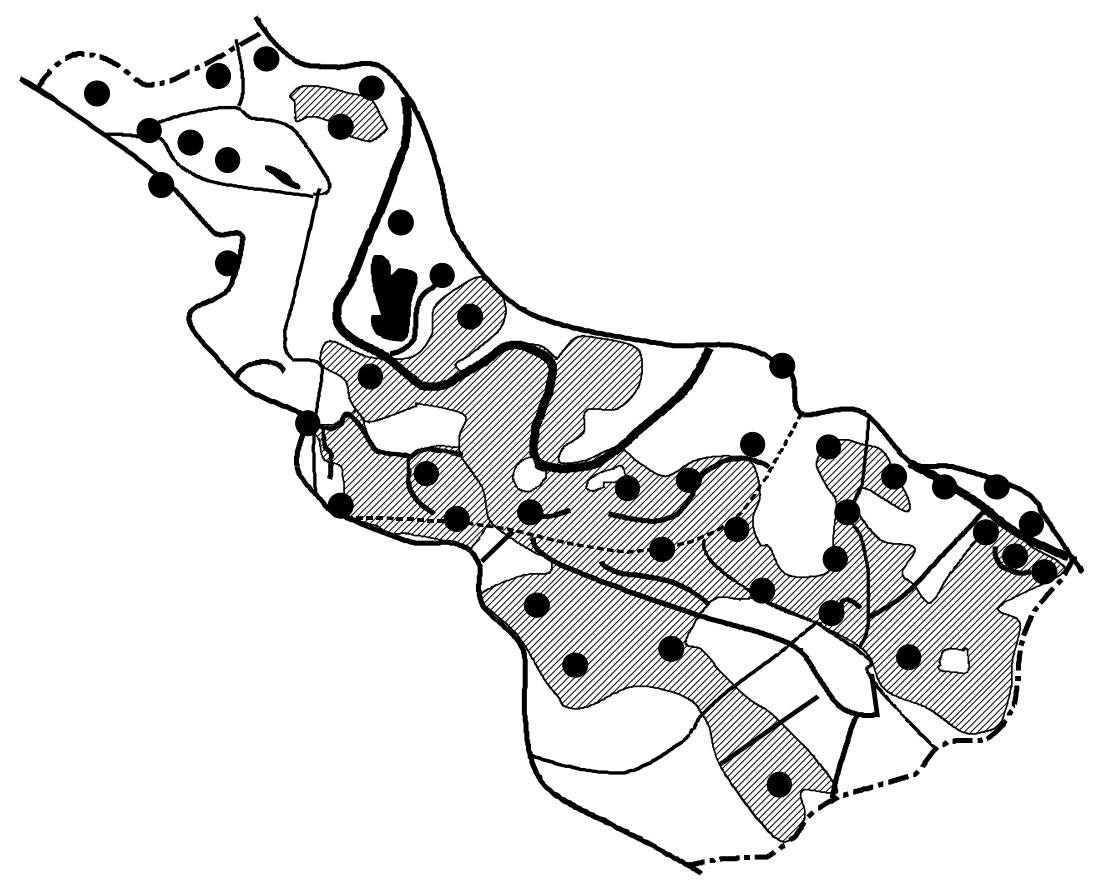

Fig 17: Distribution of Oriolus oriolus breeding pairs in Special Protection Area Natura 2000 "Grądy Odrzański” in Czernica and Siechnice counties, Wrocław district in 2009.

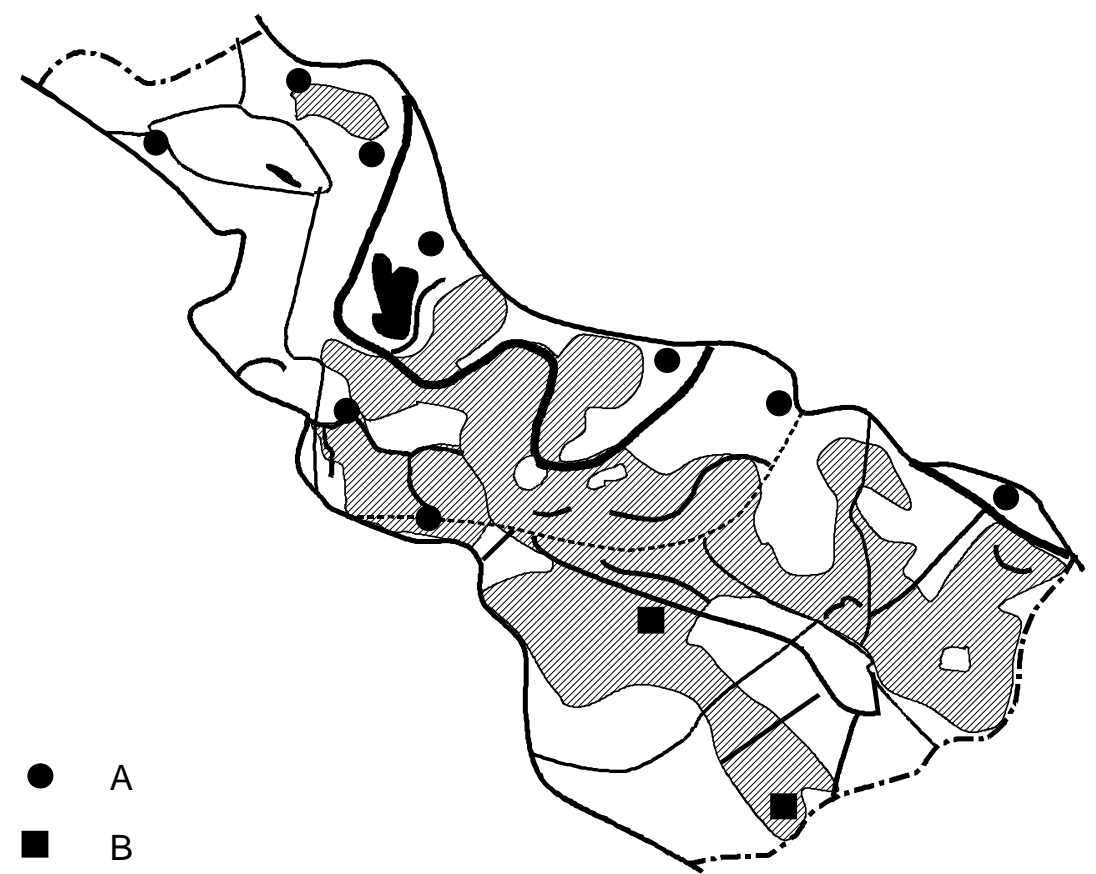

Fig 18: Distribution of Corvus cornix (A) and Corvus corax (B) breeding pairs in Special Protection Area Natura 2000 "Grądy Odrzański" in Czernica and Siechnice counties, Wrocław district in 2009. 
Tab 1: Breeding birds in forests in SPA'Grądy Odrzańskie' in Czernica and Siechnice county counted by mean of the line transect method in 2009. Explanations: $\mathrm{N}$ - number of pairs recorded, $\% \mathrm{D}-$ dominance, $\mathrm{N}_{\max }-$ maximal number of pairs recorded in any of the six distinguished periods, $\mathrm{D}_{\mathrm{mx}}$. - dominance out of the maximal numbers; II half of III - second half of March, I half of IV - first half of April, and so on.

\begin{tabular}{|c|c|c|c|c|c|c|c|c|c|c|c|c|c|c|c|c|}
\hline \multirow[t]{2}{*}{ Species } & \multicolumn{4}{|c|}{ Maen values } & \multicolumn{2}{|c|}{ II half of III } & \multicolumn{2}{|c|}{ I half of IV } & \multicolumn{2}{|c|}{ II half of IV } & \multicolumn{2}{|c|}{ II half of V } & \multicolumn{4}{|c|}{\begin{tabular}{|l|l|} 
I half of VI & II half of VII \\
\end{tabular}} \\
\hline & $\mathbf{N}$ & $\% D$ & $\mathbf{N}_{\max }$ & $\% D_{\mathrm{mx}}$ & $\mathbf{N}$ & $\% \mathrm{D}$ & $\mathbf{N}$ & $\% \mathbf{D}$ & $\mathbf{N}$ & $\% \mathrm{D}$ & $\mathbf{N}$ & $\% \mathrm{D}$ & $\mathbf{N}$ & $\% \mathrm{D}$ & $\mathbf{N}$ & $\% D$ \\
\hline Fringilla coelebs & 633 & 16.0 & 182 & 12.6 & 81 & 20.9 & 182 & 21.4 & 127 & 11.5 & 78 & 13.1 & 124 & 16.8 & 41 & 14.4 \\
\hline Sturnus vulgaris & 277 & 7.0 & 125 & $\begin{array}{ll}8.7 \\
\end{array}$ & 44 & 11.3 & 125 & 14.7 & 58 & 5.3 & 45 & 7.6 & 5 & 0.7 & 0 & 0.0 \\
\hline Sylvia atricapilla & 253 & 6.4 & 100 & 6.9 & 0 & 0.0 & 4 & 0.5 & 100 & 9.1 & 52 & 8.7 & 71 & 9.6 & 26 & 9.1 \\
\hline Parus major & 247 & 6.2 & 73 & 5.1 & 43 & 11.1 & 51 & 6.0 & 73 & 6.6 & 22 & 3.7 & 53 & 7.2 & 5 & 1.8 \\
\hline Phylloscopus collybita & 241 & 6.1 & 86 & 6.0 & 3 & 0.8 & 52 & 6.1 & 86 & 7.8 & 36 & 6.0 & 37 & 5.0 & 27 & 9.5 \\
\hline Emberiza citrinella & 228 & 5.8 & 63 & 4.4 & 4 & 1.0 & 14 & 1.6 & 62 & 5.6 & 51 & 8.6 & 63 & 8.6 & 34 & 11.9 \\
\hline Turdus merula & 215 & 5.4 & 50 & 3.5 & 19 & 4.9 & 28 & 3.3 & 48 & 4.4 & 33 & 5.5 & 50 & 6.8 & 37 & 13.0 \\
\hline Sitta europaea & 189 & 4.8 & 70 & 4.8 & 32 & 8.2 & 70 & 8.2 & 37 & 3.4 & 8 & 1.3 & 30 & 4.1 & 12 & 4.2 \\
\hline \begin{tabular}{|l} 
Parus caruleus \\
\end{tabular} & 180 & 4.6 & 61 & 4.2 & 30 & 7.7 & 61 & 7.2 & 45 & 4.1 & 20 & 3.4 & 21 & 2.9 & 3 & 1.1 \\
\hline Dendrocopos major & 180 & 4.6 & 54 & 3.7 & 26 & 6.7 & 54 & 6.4 & 37 & 3.4 & 11 & 1.8 & 40 & 5.4 & 12 & 4.2 \\
\hline Erithacus rubecula & 171 & 4.3 & 52 & 3.6 & 9 & 2.3 & 52 & 6.1 & 35 & 3.2 & 12 & 2.0 & 30 & 4.1 & 33 & 11.6 \\
\hline Turdus philomelos & 148 & 3.7 & 34 & 2.4 & 21 & 5.4 & 29 & 3.4 & 27 & 2.5 & 17 & 2.9 & 34 & 4.6 & 20 & 7.0 \\
\hline Coccothraustes coccothraustes & 70 & 1.8 & 48 & 3.3 & 5 & 1.3 & 16 & 1.9 & 48 & 4.4 & 1 & 0.2 & 0 & 0.0 & 0 & 0.0 \\
\hline Carduelis carduelis & 64 & 1.6 & 28 & 1.9 & 0 & 0.0 & 8 & 0.9 & 28 & 2.5 & 12 & 2.0 & 16 & 2.2 & 0 & 0.0 \\
\hline Muscicapa strita & 55 & 1.4 & 22 & 1.5 & 0 & 0.0 & 0 & 0.0 & 10 & 0.9 & 22 & 3.7 & 22 & 3.0 & 1 & 0.4 \\
\hline Luscinia megarhynchos & 54 & 1.4 & 21 & 1.5 & 0 & 0.0 & 0 & 0.0 & 21 & 1.9 & 16 & 2.7 & 17 & 2.3 & 0 & 0.0 \\
\hline Phylloscopus sibilatrix & 52 & 1.3 & 30 & 2.1 & 0 & 0.0 & 0 & 0.0 & 30 & 2.7 & 11 & 1.8 & 10 & 1.4 & 1 & 0.4 \\
\hline Sylvia communis & 37 & 0.9 & 16 & 1.1 & 0 & 0.0 & 0 & 0.0 & 10 & 0.9 & 16 & 2.7 & 11 & 1.5 & 0 & 0.0 \\
\hline Phylloscopus trochilus & 36 & 0.9 & 28 & 1.9 & 0 & 0.0 & 0 & 0.0 & 28 & 2.5 & 4 & 0.7 & 4 & 0.5 & 0 & 0.0 \\
\hline Parus palustris & 34 & 0.9 & 11 & 0.8 & 8 & 2.1 & 11 & 1.3 & 9 & 0.8 & 2 & 0.3 & 1 & 0.1 & 3 & 1.1 \\
\hline Passer montanus & 34 & 0.9 & 14 & 1.0 & 0 & 0.0 & 7 & 0.8 & 14 & 1.3 & 11 & 1.8 & 1 & 0.1 & 1 & 0.4 \\
\hline \begin{tabular}{|l|} 
Oriolus oriolus \\
\end{tabular} & 33 & 0.8 & 17 & 1.2 & 0 & 0.0 & 0 & 0.0 & 2 & 0.2 & 17 & 2.9 & 10 & 1.4 & 4 & 1.4 \\
\hline Carduelis chloris & 32 & 0.8 & 10 & 0.7 & 6 & 1.5 & 4 & 0.5 & 5 & 0.5 & 6 & 1.0 & 10 & 1.4 & 1 & 0.4 \\
\hline Troglodytes troglodytes & 27 & 0.7 & 8 & 0.6 & 6 & 1.5 & 8 & 0.9 & 5 & 0.5 & 2 & 0.3 & 3 & 0.4 & 3 & 1.1 \\
\hline Columba palumbus & 27 & 0.7 & 7 & 0.5 & 4 & 1.0 & 5 & 0.6 & 5 & 0.5 & 7 & 1.2 & 4 & 0.5 & 2 & 0.7 \\
\hline Dendrocopos medius & 25 & 0.6 & 14 & 1.0 & 3 & 0.8 & 14 & 1.6 & 8 & 0.7 & 0 & 0.0 & 0 & 0.0 & 0 & 0.0 \\
\hline Garrulus glandarius & 23 & 0.6 & 15 & 1.0 & 3 & 0.8 & 15 & 1.8 & 1 & 0.1 & 2 & 0.3 & 2 & 0.3 & 0 & 0.0 \\
\hline Ficedula albicollis & 23 & 0.6 & 16 & 1.1 & 0 & 0.0 & 0 & 0.0 & 16 & 1.5 & 5 & 0.8 & 2 & 0.3 & 0 & 0.0 \\
\hline \begin{tabular}{|l|l} 
Jynx torquilla \\
\end{tabular} & 23 & 0.6 & 14 & 1.0 & 0 & 0.0 & 0 & 0.0 & 14 & 1.3 & 6 & 1.0 & 2 & 0.3 & 1 & 0.4 \\
\hline Aegithalos caudatus & 21 & 0.5 & 9 & 0.6 & 9 & 2.3 & 4 & 0.5 & 4 & 0.4 & 1 & 0.2 & 3 & 0.4 & 0 & 0.0 \\
\hline Serinus serinus & 21 & 0.5 & 11 & 0.8 & 0 & 0.0 & 0 & 0.0 & 11 & 1.0 & 2 & 0.3 & 8 & 1.1 & 0 & 0.0 \\
\hline Buteo buteo & 19 & 0.5 & 9 & 0.6 & 9 & 2.3 & 2 & 0.2 & 4 & 0.4 & 1 & 0.2 & 1 & 0.1 & 2 & 0.7 \\
\hline Dendrocopos minor & 18 & 0.5 & 9 & 0.6 & 2 & 0.5 & 4 & 0.5 & 9 & 0.8 & 1 & 0.2 & 1 & 0.1 & 1 & 0.4 \\
\hline Dryocopus martius & 18 & 0.5 & 5 & 0.3 & 3 & 0.8 & 5 & 0.6 & 4 & 0.4 & 2 & 0.3 & 3 & 0.4 & 1 & 0.4 \\
\hline Locustella naevia & 18 & 0.5 & 6 & 0.4 & 0 & 0.0 & 0 & 0.0 & 6 & 0.5 & 6 & 1.0 & 5 & 0.7 & 1 & 0.4 \\
\hline Hippolais icterina & 18 & 0.5 & 11 & 0.8 & 0 & 0.0 & 0 & 0.0 & 0 & 0.0 & 11 & 1.8 & 7 & 1.0 & 0 & 0.0 \\
\hline Cuculus canorus & 18 & 0.5 & 9 & 0.6 & 0 & 0.0 & 0 & 0.0 & 4 & 0.4 & 9 & 1.5 & 5 & 0.7 & 0 & 0.0 \\
\hline Phasianus colchicus & 17 & 0.4 & 8 & 0.6 & 0 & 0.0 & 0 & 0.0 & 8 & 0.7 & 5 & 0.8 & 4 & 0.5 & 0 & 0.0 \\
\hline \begin{tabular}{|l|} 
Anthus trivialis \\
\end{tabular} & 16 & 0.4 & 13 & 0.9 & 0 & 0.0 & 0 & 0.0 & 13 & 1.2 & 1 & 0.2 & 2 & 0.3 & 0 & 0.0 \\
\hline Locustella fluviatilis & 16 & 0.4 & 6 & 0.4 & 0 & 0.0 & 0 & 0.0 & 0 & 0.0 & 5 & 0.8 & 5 & 0.7 & 6 & 2.1 \\
\hline Certhis familiaris & 15 & 0.4 & 6 & 0.4 & 4 & 1.0 & 3 & 0.4 & 6 & 0.5 & 2 & 0.3 & 0 & 0.0 & 0 & 0.0 \\
\hline Corvus corax & 14 & 0.4 & 4 & 0.3 & 1 & 0.3 & 4 & 0.5 & 3 & 0.3 & 3 & 0.5 & 2 & 0.3 & 1 & 0.4 \\
\hline \begin{tabular}{|l|l} 
Picus viridis \\
\end{tabular} & 13 & 0.3 & 5 & 0.3 & 5 & 1.3 & 2 & 0.2 & 3 & 0.3 & 1 & 0.2 & 1 & 0.1 & 1 & 0.4 \\
\hline Sylvia curruca & 11 & 0.3 & 7 & 0.5 & 0 & 0.0 & 0 & 0.0 & 7 & 0.6 & 1 & 0.2 & 3 & 0.4 & 0 & 0.0 \\
\hline Certhia brachydactyla & 10 & 0.3 & 4 & 0.3 & 0 & 0.0 & 4 & 0.5 & 3 & 0.3 & 0 & 0.0 & 3 & 0.4 & 0 & 0.0 \\
\hline Picus canus & 9 & 0.2 & 4 & 0.3 & 2 & 0.5 & 2 & 0.2 & 4 & 0.4 & 1 & 0.2 & 0 & 0.0 & 0 & 0.0 \\
\hline Remiz pendulinus & 9 & 0.2 & 9 & 0.6 & 0 & 0.0 & 0 & 0.0 & 9 & 0.8 & 0 & 0.0 & 0 & 0.0 & 0 & 0.0 \\
\hline Regulus regulus & 8 & 0.2 & 5 & 0.3 & 0 & 0.0 & 5 & 0.6 & 0 & 0.0 & 3 & 0.5 & 0 & 0.0 & 0 & 0.0 \\
\hline Sylvia borin & 8 & 0.2 & 7 & 0.5 & 0 & 0.0 & 0 & 0.0 & 0 & 0.0 & 7 & 1.2 & 0 & 0.0 & 1 & 0.4 \\
\hline Accipiter gentilis & 7 & 0.2 & 2 & 0.1 & 2 & 0.5 & 2 & 0.2 & 2 & 0.2 & 0 & 0.0 & 1 & 0.1 & 0 & 0.0 \\
\hline Motacilla alba & 7 & 0.2 & 4 & 0.3 & 0 & 0.0 & 0 & 0.0 & 0 & 0.0 & 4 & 0.7 & 2 & 0.3 & 1 & 0.4 \\
\hline Anas platyrhynchos & 6 & 0.2 & 2 & 0.1 & 0 & 0.0 & 1 & 0.1 & 2 & 0.2 & 1 & 0.2 & 2 & 0.3 & 0 & 0.0 \\
\hline Prunella modularis & 6 & 0.2 & 4 & 0.3 & 0 & 0.0 & 0 & 0.0 & 4 & 0.4 & 0 & 0.0 & 1 & 0.1 & 1 & 0.4 \\
\hline Corvus cornix & 4 & 0.1 & 2 & 0.1 & 0 & 0.0 & 0 & 0.0 & 2 & 0.2 & 2 & 0.3 & 0 & 0.0 & 0 & 0.0 \\
\hline Streptopelia decaocto & 4 & 0.1 & 2 & 0.1 & 0 & 0.0 & 0 & 0.0 & 2 & 0.2 & 1 & 0.2 & 1 & 0.1 & 0 & 0.0 \\
\hline Turdus viscivorus & 3 & 0.1 & 3 & 0.2 & 3 & 0.8 & 0 & 0.0 & 0 & 0.0 & 0 & 0.0 & 0 & 0.0 & 0 & 0.0 \\
\hline Sylvia nisoria & 3 & 0.1 & 2 & 0.1 & 0 & 0.0 & 0 & 0.0 & 0 & 0.0 & 1 & 0.2 & 2 & 0.3 & 0 & 0.0 \\
\hline Lulula arborea & 2 & 0.1 & 1 & 0.1 & 0 & 0.0 & 0 & 0.0 & 1 & 0.1 & 0 & 0.0 & 1 & 0.1 & 0 & 0.0 \\
\hline Turdus pilaris & 1 & 0.0 & 1 & 0.1 & 1 & 0.3 & 0 & 0.0 & 0 & 0.0 & 0 & 0.0 & 0 & 0.0 & 0 & 0.0 \\
\hline Parus ater & 1 & 0.0 & 1 & 0.1 & 0 & 0.0 & 1 & 0.1 & 0 & 0.0 & 0 & 0.0 & 0 & 0.0 & 0 & 0.0 \\
\hline Uрира ерорs & 1 & 0.0 & 1 & 0.1 & 0 & 0.0 & 0 & 0.0 & 1 & 0.1 & 0 & 0.0 & 0 & 0.0 & 0 & 0.0 \\
\hline Streptopelia turtur & 1 & 0.0 & 1 & 0.1 & 0 & 0.0 & 0 & 0.0 & 1 & 0.1 & 0 & 0.0 & 0 & 0.0 & 0 & 0.0 \\
\hline Lanius collurio & 1 & 0.0 & 1 & 0.1 & 0 & 0.0 & 0 & 0.0 & 0 & 0.0 & 0 & 0.0 & 0 & 0.0 & 1 & 0.4 \\
\hline Strix aluco & 1 & 0.0 & & 0.1 & 0 & 0.0 & 0 & 0.0 & 0 & 0.0 & 0 & 0.0 & 0 & 0.0 & 1 & 0.4 \\
\hline Number of pairs recorded & 3956 & & 1444 & & 388 & & 849 & & 1102 & & 596 & & 736 & & 285 & \\
\hline
\end{tabular}

